\title{
ランドサットMSSデータによる三宅島の植生分類 と火山噴火に伴う植生変化域の検出
}

$\begin{array}{llll}\text { 中 } & \text { 野 } & \text { 秀 } & \text { 人 }^{*} \\ \text { 幾 } & \text { 志 } & \text { 新 } & \text { 吉 }^{* *} \\ \text { 系 } & \text { 賀 } & & \text { 黎 }^{* * *}\end{array}$

Classification of vegetation and detection of the area of vegetation affected by the eruption using LANDSAT MSS data about Miyake Island.

Hideto NAKANO

Shinkichi KISHI

Rei ITOGA

\begin{abstract}
摘要：1983年に噴火した三宅兒の噴火前後の植生変化をランドサットデータから解析した。まず、季節変化を利用 して噴火前の植生を分類し、次に、噴火による噴出物の分布域を検出し、さらに、その植生変化域を検出した。最

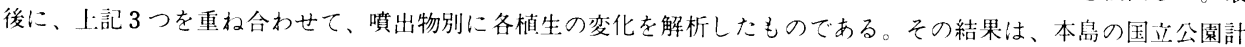
画の基礎資料として、迅速にしかも時番列的に環境変化を把握する手法として有益なものである。
\end{abstract}

\section{1. はじめに}

昭和58年（1983）10月 3 日，三宅島で21年ぶりに噴火 が起り,島の南側が大被害を受けた。

そこで本研究では, 広域同時把握, 周期的しかも経済的 な観湘, 情報のディジタル化による他情報との併用が容易, 近赤外情報の取得が容易に得られるといった利点を持 つ衛星りモートセンシングの技術を利用して，季節変化を 利用した噴火前の植生分類と噴火 10 力月後の植生変化域 の検出を行い，それらを幾志 $(1984)^{1)}$ による噴出物分布 域の検出結果亡重ね合わせて，その結果から各植生の噴 火に伴う変化を考察した2) 3)

本研究では, 植生災害調査に衛星りモートセンシング を利用し，それを国立公園計画等の基礎資料とするもの である。

\section{2. 解析システムム ${ }^{4)}$ )}

(1) ランドサット

ランドサット（Landsat 地球観測衛星）は陸域観測 を主な目的とするリモートセンシング衛星である。

本研究で使用したランドサット・データはすべて宇宙 開発事業団でバルク補正（衛星の姿勢デー夕を用いた広 範囲の幾何学的歪みに関する基礎的処理）されたランド サットーMSS (Multi Spectral Scanner) - C C T (Computer Compatible Tape) データである。ラン ドサットーM S Sは, バンド 4 ・ 5 ・6・7 という4つ の波長帯を用いて地上解像力 $80 \mathrm{~m}$ で地球表面を観測して いる。このうち植生は, クロロフィルの否吸収帯である
バンド 7 の波長で記述することができるので，植生変化 域の検出にはこれを用いたが，植生分類については，ク ロロフィルの吸収帯であるバンド 5 あ加えた。 使用したランドサット・データを表一 1 亿示した。

$$
\text { 表一1 使用ランドサットデータ }
$$

\begin{tabular}{ll|c|c}
\hline 使 用 目 的 & 観測年月日 & 衛星番号 \\
植 生 分 類 & 1979.03 .01 & 3 \\
& & 1979.05 .21 & 2 \\
\hline 植生変化域抽出 & 1979.05 .21 & 2 \\
& & 1983.10 .25 & 4 \\
& & 1984.08 .08 & 4 \\
\hline
\end{tabular}

(2) 解析対象域

解析対象域は, 北緯 $34^{\circ} 2^{\prime} 30^{\prime \prime}$ から $34^{\circ} 5^{\prime} 00^{\prime \prime}$, 東経 $139^{\circ}$ $27^{\prime} 00^{\prime \prime}$ から $139^{\circ} 34^{\prime} 30^{\prime \prime}$ でできる四角形内の本島陸域と したが、これは本島の南部にあたる。その理由は, 噴出 物分布域がての地域内に限られていること之, 乙の地域 内のもので解析可能なデータが多かったてとによる。

(3) 地理補正と輝度補正

使用したランドサット・データは, バルク補正された ものであるが，実用上は画像と地形図との位置対応をつ けるため, さらに画像座標系を経緯度に基づく地図座標 系に変換する必要がある。乙の補正は, 適当に選定した 数個の G C P (地上基準点) の両座標系における座標値 を用い, 最小二乗法により両座標系の間に変換式を求め 画像データを経緯度メッシュに従ってリサンプリング（再 配列，ニアレスト・ネイバー法）するてとにより行った。 メッシュの刻みは経度 2.25 ”, 緯度 $1.875 ”$ とした。乙れ は 2 万 5 千分の 1 の地形図の横を 200 等分, 縦を 160 等 分したもので一辺約 $57.7 \mathrm{~m}$ の正方形に近い大きさとな

*東京都建設局光が丘公園管理事務所 $\quad * *$ 科学技術庁国立防災科学技術センター第 4 研究部 
り，バルク補正後の大きさにほぼ 相当する。

一方, 地表状態が全く同じでも 太陽高度, MSSのゲインの違いの ため C C T に記録されている画像 濃度が異ってくるため, 地理補正 が施された 2 時期の画像の一方の 輝度レベルを他方のそれに变換す る必要がある。乙の補正は 2 時期 画像中で季節変化等の経時変化の ないとみなされる領域内のデー夕 から一次回帰式を決定して行った。40 輝度補正はすべて 8 月の画像を基 準とした。

\section{3. 植生分類}

(1) 分類手法

解析対象域内には, 東京都現存 植生図 ${ }^{6)}$ (以下, 現存植生図) $飞$ よると凡例が29あるが, ランドサ ット・データからてれらの凡例に 分類するととは不可能である。な

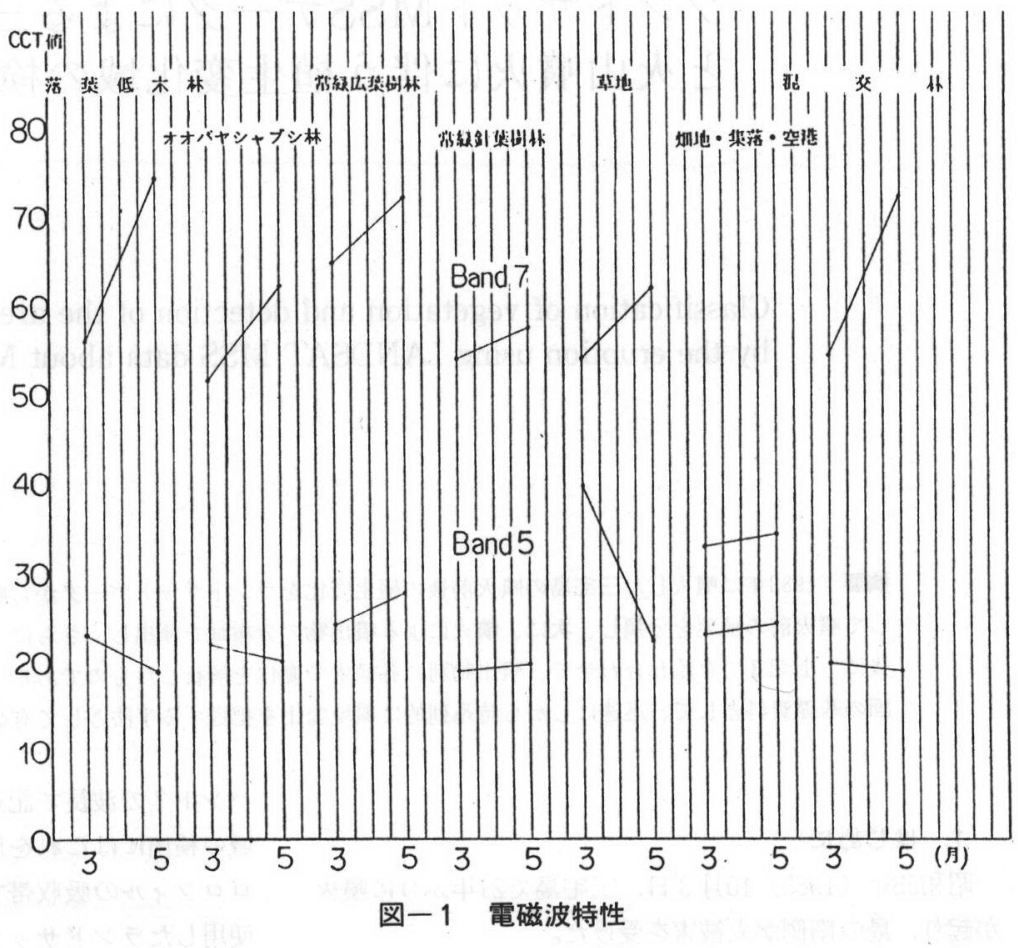

ぜならば, 現存植生図では植物社会学的に標徴種を基に 調査しているのに対し, ランドサット・データでは土地 表一2 ランドサット植生図項目とそれに対応する現存 植生図凡例

\begin{tabular}{|c|c|}
\hline ランドサット分類項目 & 生 \\
\hline 落莱 低 木 林 & 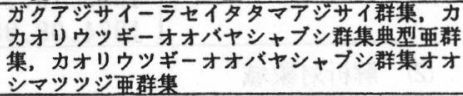 \\
\hline 常绿広葉樹林 & $\begin{array}{l}\text { オオシマカンスゲースダジイ群集, イノデータ } \\
\text { ブ群集 }\end{array}$ \\
\hline オオバヤシャブシ林 & オオバヤシャブシ植林 \\
\hline 常绿針荟梪林 & スギ・ヒノキ植㷊，クロマツ植麻 \\
\hline 徨交 & $\begin{array}{l}\text { スダジイ・タブ萌芽林，オオシマサクラーシロ } \\
\text { ダモ群集 }\end{array}$ \\
\hline$\overline{\bar{r}}$ & $\begin{array}{l}\text { 敬牧草地，牧草地，ササ原およびハチジョウス } \\
\text { スキ草原伐操跡地植群落 }\end{array}$ \\
\hline 㚼地・菒落・空港 & 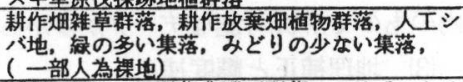 \\
\hline 末 & 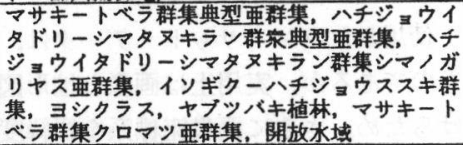 \\
\hline
\end{tabular}

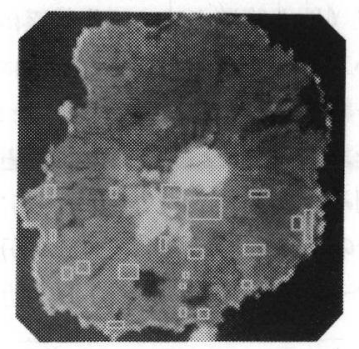

写真ー1 トレーニングエリア

を被覆している物質の電磁波特性（分光反射特性）で分 類するので, 植生が異っていてもての特性が似ていれば 画像上では区別しにくい。そのため, 現存植生図の各凡 例でとには分類できないものの，現地において色彩上似 た植生は似た電磁波特性を示すすのと予想し, 各植生の 上層部を考え, そこを占める植物の葉の形態等に注目し てまた, 現存植生図と航空写真 ${ }^{7)}$ を参考にして 7 つの項 目に分類することにした。ての 7 つのランドサット・デ 一夕による植生分類項目とそれらに対応すると考えた現 存植生図の凡例を表一 2 に示した。ここで, 分布面積が 狭い植生等については分類不可能と考え未分類とした。

以上の上うに分類項目が決定したならば, 各分類項目 をカバーするように太陽光に対する地形の向きを考慮し て22カ所のトレーニング・エリア注1) (写真 1 ) を選定し, それを基に 3 月と 5 月の 2 時期 4 チャンネル画像に対し て最尤法による分類を行った。こてで参考として各分類 項目の代表的な電磁波特性を図一 1 に示した。一般に植 生が盛んになるとバンド 7 は上がりバンド 5 は下がる。 この傾向は落葉系の植生の方が大きいととがわかる。

(2) 結果と考察

ランドサット・データを解析することにより得られた 植生分類結果を図一 2 に示した。乙の図に見るような出 力方法は, 画像表示だけでなく地図上に直接マッピング して初めて実用性をむつという観点から開発された方法 である8

このランドサット・データによる分類結果を評価する 
一つの方法として現存植生図と対比してみると, 全体的 に各分類項目の分布をよく示した，つまり集落や空港の 位置, 海岸部に多いオオバャシャブシ林, 山簏を占める 混交林と常緑針葉樹林, 草地の位置, 山地带の落葉低木 林など本島の特徴である同心円状に植生か配置されてい るのがよくあらわれている。

ここで，各分類項目でとに考察する。

落葉低木林の項目では，あえて同じ落葉樹林である才 オバャシャブシ林と項目を分けて分類を行ったが，はっ きり分布域を分けることができた。これは, 両者の種構 成の違い（自然林と植林）と, 低木林之高木林では着葉 の仕方が違うなどの点から, 異った電磁波特性を示した ものと考えられる。

オオバャシャブシ林に対する現存植生図での凡例の分 布域は海岸沿いの環状道路周辺であり，本研究でもその 結果はよく出た。しかし, オオバヤシャブシ（Alnus Sieboldiana）が現実に島のいたる所に存在するため, 量的 (画素数)に多い結果となった。

常緑広葉樹林に対する現存植生困での凡例の分布域は 人為の加わりにくい古い火口壁や急な斜面であるため, 地形の影響を受けてランドサット・データからの分類は 困難之考えた。しかし，本島の極相林であり，かつ特別 保護地区に指定されている地域等にあたる項目なのであ えて分類を試みた。想定されたとおり好結果は得られな かった。

常緑針葉樹林の項目では，山麓にスギ・ヒノキが数多 く植林されており, 島の重要な土地利用となっているて と之，噴火の影響を受けやすい植生でもあるととから分 類を試みた。結果はいくつかの問題はあるものの, 全体 的に分布域は現存植生図とほぼ一致した。

混交林に対する現存植生図の凡例では, 対象域の 3 分 の 1 を占めていた。この結果でも広域にわたって分布し ているととがわかる。しかし，混交林といっても常緑樹 の割合の高い所や落葉樹の割合の高い所があり一様でな いため, ある所では常緑樹系の項目として，ある所では 落葉樹系の項目として分類されてしまい, 現存植生困の ようにはいかなかった。

草地の項目は次に述べる畑地等の項目と区別できるか どうかが力ギであったが，村営牧場についてはその目的 を果たしたが，手島牧場ではうまくいかなかった。これ は 5 月の段階で手島牧場の牧草の生育が遅く, 土の露出 が大きかったことによると考察される。

畑地・集落・空港の項目は, 一般に電磁波特性は似て いないので本来は別々に分類すべきであるが，本島では 何れも面積が狭く分類が困難で, しかも集落といっても 緑が多く, 空港といっても芝等で緑が多く，3つの緑被 率が似ていて，また 3 つの電磁波特性も本島では似てい たので, 無機物と植物が混合する地域としてまとめるこ
とにした。結果は，現存植生図とほぼ一致した。

以上のことから，ランドサット・データを使えば植牛 の分布域を検出する可能性があると考察される。ここで 主な不一致筒所をあげると，島の東側と西側では差があ り, 東側では現存植生図とほぼ分布パターンは一致した が，西側では太陽光に対して地形の影響を受け影の部分 となった所があり，それが本来とは異った電磁波特性之 誤認され, 混交林の所が常緑針葉樹等に誤分類されてし まった。また，新零池周辺や大路池周辺の急斜面でも同 椂に地形の関係で, 本来常緑広葉樹林の項目の所が常緑 針葉樹林等の項目に誤分類されてしまった。その他，落 葉低木林之常緑針葉樹林の項目が接すべき所（婎山の南 東部）に混交林が示され，また，海岸付近の未分類であ る自然裸地と各植生が接する所に烟地・集落・空港の項 目が示されてしまった。てれらは各植生の接点ではラン ドサット・データから正確に分類することが限界である ことを意味すると考えられる。

次に参考として, 量的に両植生図を比較するため, 現 存植生図にランドサット・データの再配列と同一のメッ シュをかけた。その両者の比較を面積に関し, 表一 3 に 示した。

\section{表一－ランドサット植生分類結果と現存植生図との 面積比較}

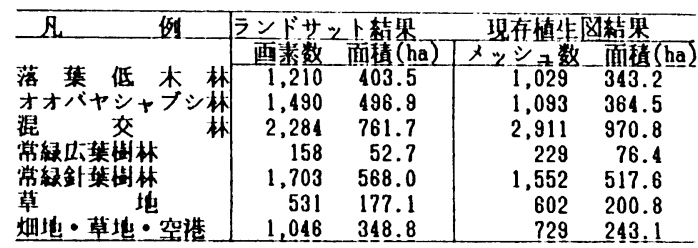

但し（1画啋 $=1 \times ッ シ ュ=57.7 ロ \times 57.8 m=0.333506 \mathrm{ha} ）$

これによると, 特に畑地・集落・空港とオオバヤシャ ブシ林の項目で大きな誤差が出た。以下䛊差の大きい順 にみると, 常緑広葉樹林・落葉低木林・混交林・常緑針 葉樹林そして草地であった。

\section{4. 植生変化域の検出}

(1) 解析方法

今回の噴火により何らかの変化が顕著にあらわれた地 域を検出するため, 噴火の翌年の夏のデータを噴火前の 初夏のデータと比較した。(一部地域に噴火直後のデー 夕6使用した。）乙れは輝度補正の済んだバンド7の 2 時 期の画像に対し差画像注2）を作成して行った。乙でで植 生変化域の検出にあたり, 輝度補正㗊差を評価するため, 噴火や雲の影響がない地域における 2 時期の差の值につ いて平均值と標準偏差を統計量として求めた。すなわち, 補正した噴火前の画像の輝度之噴火後の画像の輝度差の 島東部の常緑樹林に打ける平均值之標準偏差を表一 4 に 示した。そして, その差画像から噴火前後の輝度差が先 に求めた差の標準偏差以上の領域を植生が変化した可能 
表一 4 噴火前後の輝度差と標準偏差

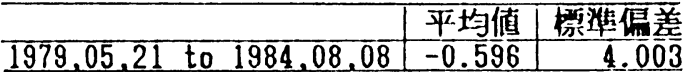

性が高い地域として検出した。こてでは, 変化が強い地 域の検出ということで, 発生確率の極めて低い範囲に相 当する $3 \sigma(=12.009)$, 輝度差12（単位は C C T値）以 上を植生変化域とし, 輝度差11以下の地域は变化なし, あるいはほとんどなしとみなし検出しなかった。

(2) 結果抢よび考察

結果を図一 3 亿示し，画素数および面積を表一 5 に示 した。この結果を噴出物分布域の検出結果（図一 4) と 比較しながら以下考察を加える。

\section{表一 5 植生変化域の画素数と面積}

\begin{tabular}{c|c|c}
\hline & 画 素 数 & 面皘 $(\mathrm{ha})$ \\
\hline 变化域 & 1,988 & 663.0 \\
\hline
\end{tabular}

噴火後10力月で植生に顕著な変化があらわれている地 域は，雄山南西部の地点を始点とし阿古集落方向と新澪 池方向へ向った大小 4 つの線状の流れの地域と, 新澪池 から大路池をへて畜産試験場に至る帯状の地域であるこ とがわかる。これは図一 4 を見ればわかるように溶岩・ スコリア・噴石および大量の火山灰降下域（降下深 256 m以上）とほぼ一致する。つまり，乙れらの噴出物降下 域で植生変化が大きかったことがわかる。しかしここで 問題なのは, 確かに変化が大きかった地域の検出はでき たが，例えば常緑広葉樹林なら木がすべて枯れてしまっ たのか, それとも落葉してしまい回復が遅れているてと により今回の調査では変化域として検出されてしまった のかどうかわからないてとである。乙の点は今後の研究 課題として, 今回の研究では概要を迅速に把握し, 現地 調査への基礎資料とすることを主たる目的としたもので ある。

\section{3 画像の重ね合わせ}

いままでの 2 結果に噴出物分布域の検出結果を重ね合 わせ, 各植生の噴出物別降下面積を求め, さらにその面 積中どの位の面積に变化があらわれているかを電算処理 し，表一6に示した。

表一 6 からわかるように，噴出物降下面積の占める割 合が高かった植生は常緑広葉樹林であった。面積そのも のでは混交林が一番降下が多く, 以下常緑針葉樹林・才 オバヤシャブシ林・落葉低木林・草地・常緑広葉樹林で あった。

次に噴出物別に見ると, 各植生とも・溶岩・噴石・ス コリアの降下域で $90 \%$ 以上の変化が見られ，大量の火山 灰降下域でもオオバャシャブシ林を除いて同様な結果を 得た。乙てで, オオバャシャブシ林だけ大量の火山灰降 下域で変化の割合が他の植生に比べ低かったてとから, この植生は他の植生に比べ回復が速いと予想される。噴
出物が中量の火山灰降下域（降下深64以上 256 m 未満） ともなると各植牛によってばらつき, 常緑系より落葉系 の植生の方が変化が少ないてとがわかる。これは常緑樹 が一度落葉すると回復が遅いか枯れてしまうことからも 納得できる。少量の火山灰降下域（降下深 $64 \mathrm{~mm}$ 未満）で は, 各植生とも大きな変化はあらわれなかった。

\section{6. まとめ}

(1) 2 時期の季節変化を利用して植生分類を行うと, 緩やかな斜面あるいは平地ならば各植生の分布状況が把 握できる。ただ，太陽光に対する地形の影響を受けると 㕵分類されやすい。

（2）植生分類同様経時変化を利用して差画像を作成し それをもとに電算処理すると, 噴火に伴う植生変化域の 検出が可能である。

(3) 3 画像の重ね合わせにより, 各植生とも溶岩・噴 石・スコリアおよび大量の火山灰降下域で大きな変化が 見られたてとから，その地域で被害が大きかったと考え られる。

\section{7. おわりに}

精度の面では航空機に少るといわれているランドサッ トではあるが，周期的観測を行っているため，時系列的 な環境把握を行うには利用価値は高く，また，航空機で は何枚もの写真が必要となるとてろを一つの画像で処理 できるため, 広域同時把握が可能で，火山爆発のような 大規模災害の時には有益である。また, デー夕解析結果 を地形図にマッピングすれば現地調查のための基礎資料 となり，しかも国立公園計画にも利用でき，その実用性 を発揮できる。だが，ランドサット・データのみによっ て植生区分を正確に定めるには限界がある。しかし, 現 地調查とうまく組み合わせれば，ランドサットは有効な 環境把握手法となるであろう。

本研究に使用したデータはM S S よよるあの゙あった が, これよりも観測波長带が多く解像力（約 $30 \mathrm{~m} ）$ の高 いTM (Thematic Mapper)の研究が最近盛んとなり, 今後はTMデータの活用に期待したい。

注 1 ）画像上で分類しようとする凡例に相当する領域

注 2 ) 輝度補正された同じ地域の 2 時期の画像間に変 化があれば輝度に差を生じる。その差を画像表 羊したもの。

\section{参考・引用文献}

1 ) 幾志新吉：ランドサットデータによる1983年三宅島 噴火噴出物の分布域の検出: 国立防災科学技術セン ター研究速報 51号, 19-27 1984

2 ) 中野秀人：ランドサットデータによる三宅島噴火に 伴う植生変化の解析 : 筑波大学卒業論文, 1985 


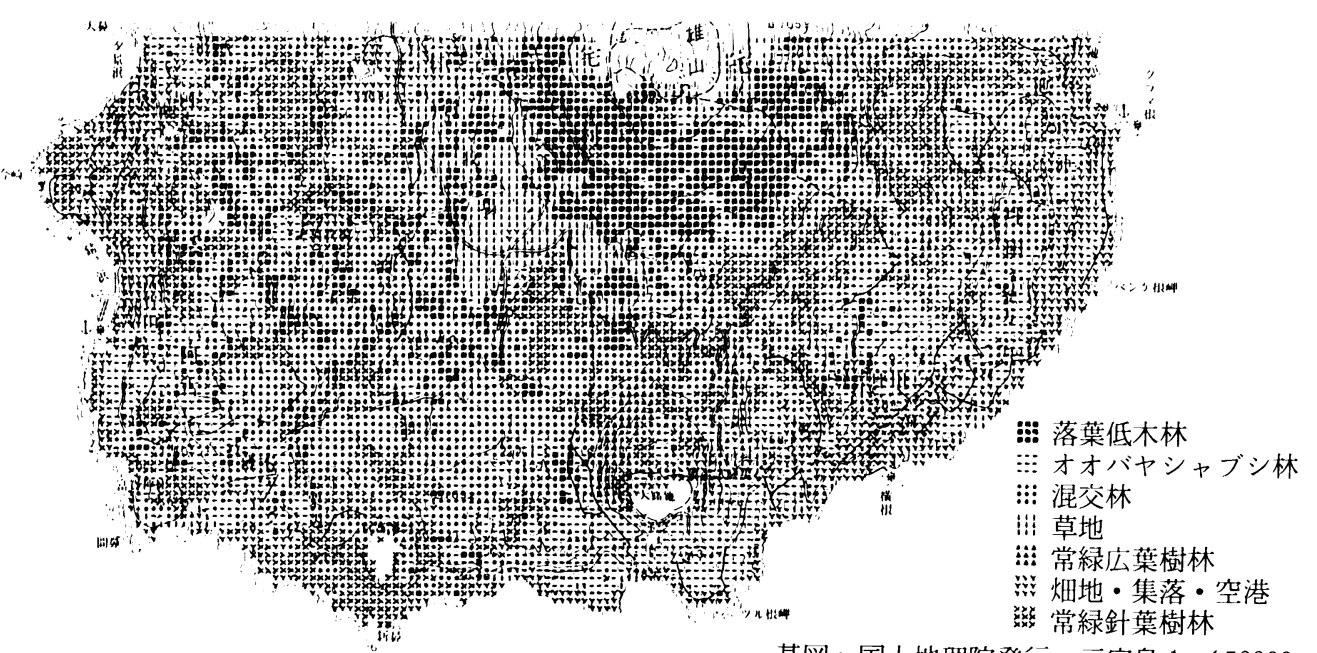

図一２植生分類結果

基図 : 国土地理院発行 三宅島 $1 / 50000$
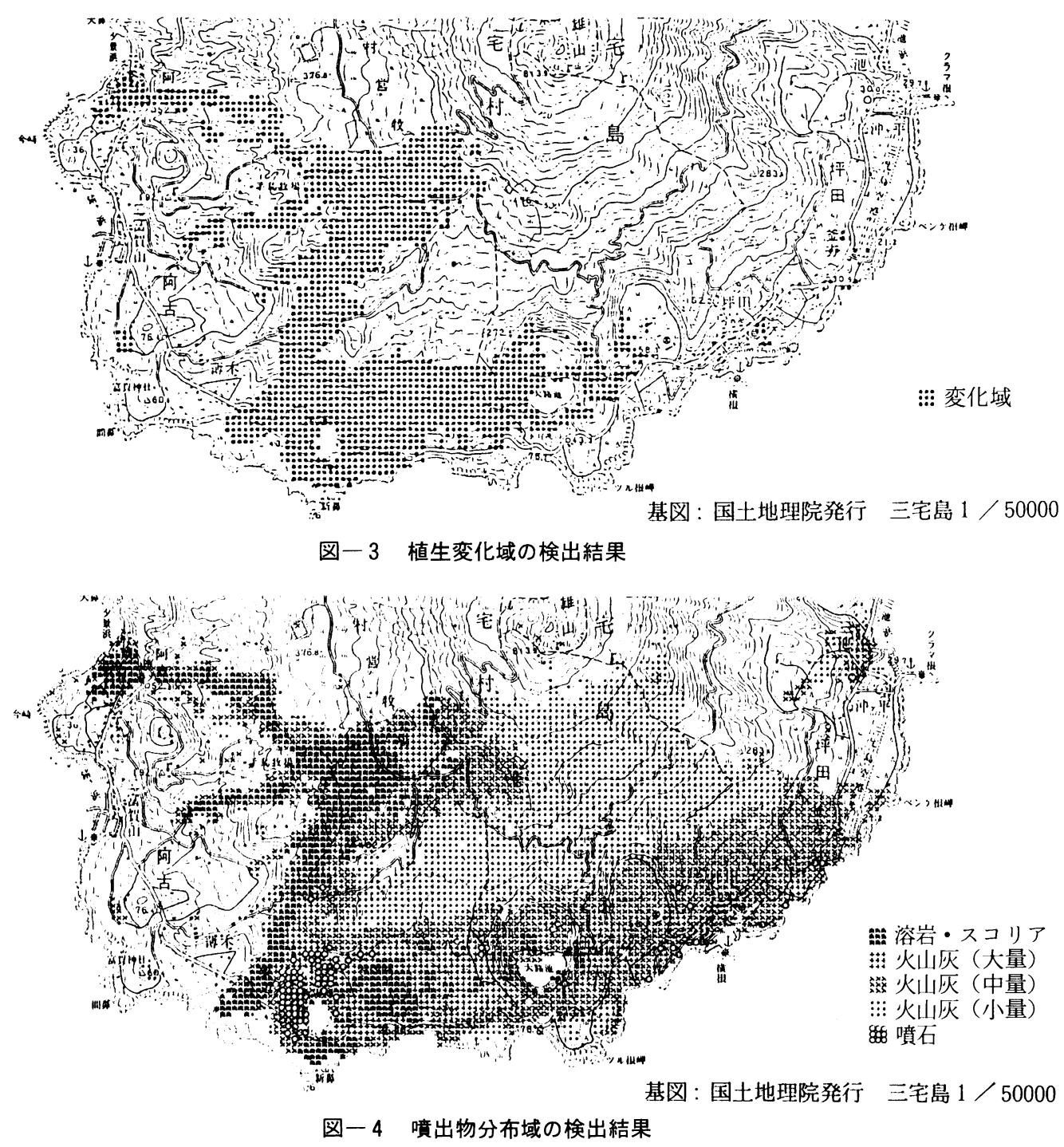
3 ）幾志新吉・中野秀人：ランドサットM S S データに よる土地被覆分類と堆積した火山噴出物の面積の測 定一1983年三宅島噴火関して一: 国立防災科学技 技センター研究速報 69 号 $3-16 \quad 1985$

4) 日本リモートセンシング研究会編 : 画像处理と解析 : 共立出版 1981

5 ）リモートセンシング技術センター: データ解析研究
報告書 : 昭和54年度科学技術庁委託 1980

6 ）奥富 清他 : 東京都現存植生図 : 東京都 1976

7 ）国土地理院発行 1978, 10, 22

8 ）幾志新吉 : ランドサット情報のマッピング手法の開 発: 写真測量学会59年度秋季学術講演会論文集 59 $-601984$

表一 $6 \quad 3$ 画像の重ね合わせによる結果

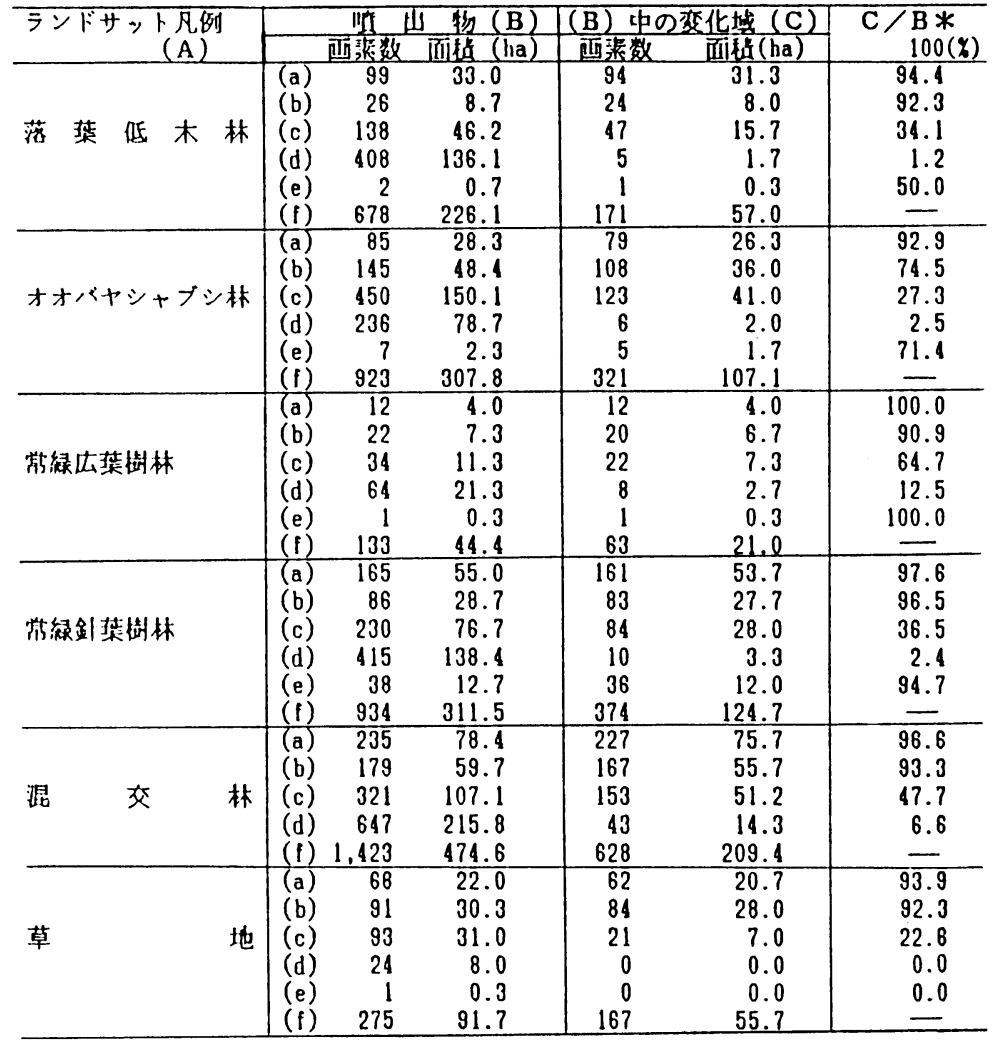

但し、㚼地・集落・空港の凡列を入れなかったのは、嘪出物が人為的に取り俆かれた 可能性が高い地域のため、表から削除した。

( 1 画素 $=1 \times ッ シ ュ=57.7 \times \times 57.8 \mathrm{~m}=0.333506 \mathrm{ba})$

(a); 溶岩、スコリア (b);大量の火山灰 (c); 中量の火山灰 (d);少量の火山斥 (e);嗔石 (f); 合計

Summary : The change of the vitality of vegetation in Miyake Island by the eruption of 1983 was investigated using LANDSAT MSS data. The study was conducted as follows.

1. Classification of the vegetation ahead of the eruption based upon the seasonal change of vegetation.

2. Detection of the area covered by the volcanic products.

3. Detection of the area of vegetation affected by the eruption.

Finally, overlaying them, the area of vegetation affected by the eruption was measured in ach area covered by the respective volcanic products.

The result is considered to be useful as the elementary data for National Park Planning in Miyake Island and as the method finding the change of environment rapidly and continu ously. 